prof. Czesław Nowak

UNIWERSYTET ROLNICZY IM. HUGONA KOŁŁĄTAJA W KRAKOWIE

\title{
Ekonomiczne i społeczne znaczenie zatrudnienia $w$ rolnictwie na przykładzie wybranych państw UE
}

\section{Wstęp}

Poza znaną, odwieczną funkcją pracy w rolnictwie, jaką jest produkcją żywności, w UE podkreślane są szczególnie jego dwie inne, będące elementami zrównoważonego rozwoju obszarów wiejskich: troska o środowisko naturalne i funkcja społeczno-kulturowa. Rozwój zrównoważony w skali makro jest możliwy dzięki „zintegrowaniu polityki środowiskowej, gospodarczej i społecznej. Wymaga to traktowania zasobów środowiska jak ograniczonych zasobów gospodarczych oraz wykorzystywania kapitału przyrodniczego w sposób pozwalający na zachowanie funkcji ekosystemów w perspektywie długookresowej”. Zaspokajanie potrzeb współczesnych nie może powodować zmniejszania szans rozwoju następnych pokoleń ${ }^{2}$. Idea ta przypomina więc przypisywaną Hipokratesowi lekarską zasadę: „Primum non nocere”, czyli „przede wszystkim nie szkodzić". W tym przypadku przyrodzie.

1 European Council of Young Farmers, Policy and publications, Statistics 2013.

2 Światowa Komisja ds. Środowiska i Rozwoju, Raport Nasza Wspólna Przyszłość, 1987. 
Analizując zatrudnienie w rolnictwie, należy pamiętać o historycznym kontekście, w jakim funkcjonowało ono w danych czasach. Najdłużej, a więc „od zawsze” głównym celem pracy w rolnictwie była produkcja żywności. Innym, chociaż często słabiej zauważanym jego aspektem było stabilizowanie życia społecznego, a więc unikanie niepokojów i zamieszek społecznych wywoływanych brakiem żywności. Hasło tłumów starożytnego Rzymu „Panem et circenses” nie było prośbą, ale żądaniem.

\section{Wyjątkowość naszych czasów}

XXI wiek zmienił jednak tę perspektywę przynajmniej z kilku powodów:

- po raz pierwszy w dziejach ludzkości liczba osób mieszkająca na wsi, a więc w środowisku produkcji rolniczej, stała się mniejsza od liczby osób mieszkających w mieście;

- po raz pierwszy w dziejach ludzkości rolnictwo przestało być największym „pracodawcą”. Największy udział w zatrudnieniu mają usługi (tabela 1);

- po raz pierwszy w dziejach ludzkości liczba ludzi z nadwaga i otyłością jest większa od liczby ludzi głodnych.

Tabela 1: Struktura zatrudnienia na świecie według sektorów gospodarki w latach 2002-2007 [\%]

\begin{tabular}{cccc} 
& $\mathbf{2 0 0 2}$ & $\mathbf{2 0 0 7}$ & ZMIANA \\
\hline ROLNICTWO & 40,9 & 37,3 & $-3,6$ \\
\hline PRZEMYSE & 20,6 & 21,7 & $+1,1$ \\
\hline USŁUGI & 38,5 & 41,0 & $+1,5$
\end{tabular}

Źródło: na podstawie The World Factbook 2013, https://www.cia.gov/library/publications/download/download-2013/ (12.10.2014). 
Ostatni punkt z pewnością nie świadczy najlepiej o podziale dóbr w naszych czasach.

Podane powyżej zmiany, świadczące o wyjątkowości naszej epoki, obrazują tło rozwoju rolnictwa na całym świecie, w tym oczywiście w Unii Europejskiej i w Polsce. Specyfika jego funkcjonowania w UE, $\mathrm{w}$ tym poziomu zatrudnienia, wynika m.in. $\mathrm{z}$ dalszego doceniania znaczenia rolnictwa dla zapewnienia bezpieczeństwa żywnościowego 28 państw członkowskich. Prawie wszystkie państwa UE, oprócz neutralnych w okresie II wojny światowej (czyli Szwecji, Irlandii, Portugalii), doświadczyły głodu bądź niedoborów żywności, trwających często jeszcze przez wiele lat po wojnie. Pamięć tamtych trudnych czasów powoduje, że odpowiedzialni politycy rozumieja, że rolnictwo jest szczególnie ważną częścią gospodarki, a jego rola nie powinna być oceniana wyłącznie $\mathrm{w}$ kategoriach opłacalności produkcji w danym roku. Bezpieczeństwo, w tym bezpieczeństwo żywnościowe, też ma swoją cenę. Odpowiedzialni politycy rozumieją także, ucząc się z historii, że wiele gwałtownych buntów społecznych wynikało nie tylko z imponderabiliów (np. potrzeby wolności), ale z niedoborów żywności, często nawet krótkotrwałych. Decydenci, nadając kształt polityce społecznej i ekonomicznej UE, pamiętali o tym i z tego punktu widzenia rolnictwo jest nadal kluczowym czynnikiem.

\section{Nowa sytuacja wokół rolnictwa}

Należy się jednak liczyć z tym, że tamto pokolenie polityków z pamięcią o latach niedoborów żywności zastanie wkrótce (w niektórych państwach już to nastąpiło) zastąpione przez polityków młodszych, dla których większym problemem niż obawa przed niedoborem 
żywności jest o wiele częściej występujący problem jej nadprodukcji. Media częściej przekazują przecież informacje o "górach masła”, "górach mięsa” zamrożonego w półtuszach, „jeziorach wina” niż o brakach żywności, a większym problemem niż głód jest w Unii Europejskiej nadwaga i otyłość jej obywateli.

Także z punktu widzenia rolników problemem nie jest obecnie wyprodukowanie towarów rolno-spożywczych, ale ich sprzedaż. Paradoksem jest jednak to, że taki stan obserwowany jest również w tych państwach członkowskich UE, w których wydatki na żywność są relatywnie wysokie. Przykładem tego jest także Polska.

Kolejny problem w UE to niechęć młodych ludzi do podejmowania pracy w rolnictwie, w tym najczęściej niechęć do kontynuowania wielopokoleniowej tradycji rodzinnej. To często skutek obserwacji życia i pracy rodziców oraz możliwości porównania jej $\mathrm{z}$ pracą $\mathrm{w}$ innych zawodach. Rolnictwo wypada $\mathrm{w}$ tym porównaniu niezbyt korzystnie - brak wolnych ma weekendów, płatnego urlopu, praca w trudnych warunkach niezależnie od pogody, duża wypadkowość itp. Także w USA zatrudnienie w rolnictwie zaliczane jest do jednej z najgorszych prac - według rankingu opublikowanego przez "The Wall Street Journal”, jeśli brane są pod uwage takie kryteria jak wysiłek fizyczny, środowisko pracy, dochód i stres, to zatrudnienie $\mathrm{w}$ rolnictwie jest na 179. miejscu, a praca dojarza na 199. spośród 200 ocenianych - od najlepszych do najgorszych.

$\mathrm{Z}$ kolei według ocen brytyjskiej agendy rządowej Health and Safety Executive, biorąc pod uwagę liczbę wypadków śmiertelnych, rolnictwo jest jednym z najbardziej niebezpiecznych zawodów. Podobnie $\mathrm{w}$ Polsce szacuje się, że wypadki przy pracy $\mathrm{w}$ rolnictwie zdarzają się dwukrotnie częściej niż w innych działach gospo- 
darki³. Biorąc więc pod uwagę różne kryteria - od warunków pracy do jej bezpieczeństwa - rolnictwo nie jest szczególnie atrakcyjną pracą dla ludzi młodego pokolenia.

W tym kontekście nie jest zaskoczeniem ustawiczny proces starzenia się rolników jako grupy zawodowej. W ten sposób następuje ciągły, z powodów naturalnych, spadek zatrudnienia w tym sektorze gospodarki. W Unii Europejskiej średnio co trzeci rolnik (34 proc.) ma ponad 65 lat. Prawie połowa rolników UE-28 ma 55 lat lub więcej, a na jednego rolnika poniżej 35 lat przypada dziewięciu, którzy mają ponad 55 lat $^{4}$. Największy odsetek rolników powyżej 65 roku życia, nadal pracujących w gospodarstwach, mają państwa o trudnej sytuacji ekonomicznej. Tak więc w Portugalii jest to 48,3 proc., w Bułgarii 45,3 proc., w Rumunii 45, o proc. Najmniej rolników z tej grupy wiekowej jest w Niemczech (7,5 proc.) i Finlandii (6,2 proc.). W Polsce jest to 16,2 proc., czyli średnio co szósty polski rolnik jest $\mathrm{w}$ wieku emerytalnym ${ }^{5}$.

Młodzi rolnicy, a więc rolnicy w wieku do 35 lat, stanowią tylko 6 proc. rolników UE. Polska ma największy udział rolników tej grupy wiekowej spośród wszystkich państw członkowskich: 16,8 proc. Najmniej korzystny pod tym względem stan jest w Rumunii: 2,9 proc., Wielkiej Brytanii: 2,8 proc. i Portugalii: 2,5 proc. To paradoksalne, dziwne sąsiedztwo Wielkiej Brytanii i państw mających trudną sytuację ekonomiczną, może wynikać ze specyfiki brytyjskiego rolnictwa - jest ono nadal w dużej mierze oparte na dużej własności ziemskiej, gdzie rolnicy są robotnikami rolnymi. Słabsze są tam

3 Z. Serwański, J. Chojnicki, Państwowa Inspekcja Pracy, Warszawa 2009.

4 European Council of Young Farmers, Policy and publications, Statistics 2013.

5 European Council of Young Farmers, Policy and publications, Statistics 2013. 
także, szczególnie w porównaniu z Francją, Irlandią, Danią czy z Polską, związki zawodowe rolników. Siła lobbingu brytyjskiej organizacji rolników National Farmers' Union jest znacznie mniejsza niż na przykład francuskiej Krajowej Federacji Związków Zawodowych Pracowników Rolnych (FNSEA) czy naszej Krajowej Rady Izb Rolniczych. Przykładem szczególnie skutecznych form obrony społecznej i ekonomicznej roli rolników, ich miejsc pracy i udziału w rynku są także spółdzielnie rolnicze Francji. Skutkiem tej solidnie społecznie osadzonej działalności jest także wskaźnik udziału ceny produktów, jaką otrzymują rolnicy w cenie detalicznej, a więc porównanie ceny u rolnika z ceną na półce sklepowej. Jeszcze pół wieku temu było to średnio około 50 proc., a obecnie we Francji jest to 18 proc., podczas gdy w Wielkiej Brytanii tylko 8 proc.

Jedną z konsekwencji tak różnej sytuacji rolników w różnych państwach Unii Europejskiej jest także stosunek poszczególnych rządów do struktury wydatków na rolnictwo z budżetu UE. Jeszcze na począt$\mathrm{ku}$ lat 70 ubiegłego wieku wynosiło ono około 70 proc. budżetu UE. W okresie realizacji perspektywy finansowej 2007-2013 było to już tylko 34 proc. ${ }^{6}$. Jednak w 20014 roku ponownie wzrosło do 41,6 proc. ${ }^{7}$.

\section{Argumenty przeciwników wysokich subsydiów do rolnictwa}

Zrozumienie potrzeby wsparcia rolnictwa z budżetu Unii Europejskiej jest oczywiście większe w tych państwach członkowskich,

6 European Commission, Agriculture, Policy Areas, 2010.

7 European Commission, Sustainable Growth. Natural Resources. Budget 2014 in figures, 2014. 
w których zatrudnienie w rolnictwie jest dwucyfrowe. Jest to grupa państw o średnim PKB per capita poniżej średniej UE, a więc o relatywnie mniejszych możliwościach wpływania na kształt budżetu UE. Należy jednak zaznaczyć, że zdecydowanym głosem za potrzebą kontynuacji takiego wsparcia jest - od początku Wspólnej Polityki Rolnej-głos Francji. Jest ona przecież największym beneficjentem tej części wydatków budżetu UE, otrzymując w różnych latach około 17-20 proc. subsydiów UE i jest także największym producentem rolnym - wartość produkcji jej rolnictwa to 19,1 proc. wartości produkcji rolnictwa Unii 8 .

Do otwartych krytyków wysokiego poziomu subsydiowania rolnictwa należy natomiast Wielka Brytania. Jej politycy argumentują, że nie ma powodu, aby 5 proc. zatrudnionych w tym sektorze gospodarki, wytwarzając tylko 1,8 proc. $\mathrm{PKB}$, otrzymywało 41,6 proc. budżetu UE9 . Ponadto, jak podkreślają przeciwnicy wysokich subsydiów do rolnictwa, w Unii większym problemem niż rolnictwo jest od lat bezrobocie.

W Wielkiej Brytanii zatrudnienie w rolnictwie wynosi zaledwie 1,4 proc. Wynika to z jednej strony ze wspomnianej uprzednio tamtejszej specyfiki własności ziemskiej, a także największej obok Czech średniej powierzchni gospodarstw. O ile średnia powierzchnia gospodarstw w UE-28 wynosi 14,5 ha (w Polsce 9,6 ha), to w Czechach i Wielkiej Brytanii odpowiednio 151 i 85,7 ha $^{10}$. Wśród polityków

8 Eurostat, Agricultural statistics, Data 1995-2005: Output value at producer prices of the agricultural industry, 2007.

9 European Commission, Sustainable Growth. Natural Resources. Budget 2014 in figures, 2014.

10 Eurostat: Surveys of the structure of agricultural holdings. Agriculture and Rural Development, 2012. 
tych państw (Czechy, Wielka Brytania) najczęściej pojawiają się argumenty przeciw - według nich nadmiernemu - faworyzowaniu rolników.

Z drugiej jednak strony należy zaznaczyć, że co pewien czas także politycy brytyjscy, często pod presją opinii publicznej, dostrzegają znaczenie rolnictwa. Przykładem takiej nieco okazjonalnej metamorfozy może tu być m.in. stan, jaki powstał w okresie katastrofy spowodowanej BSE. Jej największe nasilenie w Anglii, Szkocji i Walii przypadło na lata 1992-1993. Wówczas, z powodu zamknięcia dostępu turystów do wielu obszarów wiejskich, dało się mocno odczuć, jak bardzo rolnictwo powiązane jest z całą lokalną gospodarką. Straty ekonomiczne w turystyce spowodowane ograniczeniami dostępu do obszarów wiejskich przewyższyly straty w rolnictwie. Dopiero wówczas wielu polityków - decydentów zrozumiało, że nie ma ani turystyki wiejskiej, ani lokalnych produktów regionalnych i tradycyjnych bez rolnictwa ${ }^{11}$.

Kolejne prorolnicze wypowiedzi polityków brytyjskich pojawiły się wówczas, gdy - jak to wynikło z badań - znacznie wzrosło zainteresowanie konsumentów (a więc w praktyce wszystkich) żywnością lokalną. Opublikowane w 2011 roku wyniki 12-miesięcznych badań preferencji zakupów wykazały, że ponad dwie trzecie klientów uważa, że jest dla nich ważne, aby kupować produkty rolnictwa krajowego. W przypadku owoców i warzyw jest to trzy czwarte kupujących. Powodem takich decyzji jest przekonanie o wysokiej wartości zdrowotnej produktów krajowych, a także - co przyznaje 30 proc. - chęć wspierania własnego, brytyjskiego rolnictwa. O tym, że nie tylko cena

11 Nowak C., Turystyka wiejska w USA i w UE, „Episteme” 8 (2009) 1, s. 5-9. 
decyduje o zakupach towarów spożywczych, mówił także konserwatywny minister ds. rolnictwa Jim Paice ${ }^{12}$. Tak więc nawet niezbyt skłonni do udzielania dotacji do rolnictwa UE politycy brytyjscy dostrzegaja, przynajmniej czasami, potrzebę funkcjonowania nie tylko wyłącznie rynkowych mechanizmów w odniesieniu do rolnictwa.

\section{Rola zatrudnienia w rolnictwie w uboższych państwach UE}

Przez państwa uboższe rozumie się tutaj te państwa Unii, w których produkt krajowy brutto per capita mierzony według parytetu siły nabywczej (PPP - purchasing power parity) jest mniejszy od średniej dla całej UE.

Tabela 2: Państwa Unii Europejskiej o największym zatrudnieniu w rolnictwie w 2011 roku oraz ich bezrobocie i PKB per capita [\%].

\begin{tabular}{ccccc} 
& RUMUNIA & CHORWACJA $^{*}$ & POLSKA & GRECJA \\
\hline $\begin{array}{c}\text { ZATRUDNIENIE } \\
\text { W ROLNICTWIE }\end{array}$ & 28,6 & 15,4 & 12,7 & 12,4 \\
\hline $\begin{array}{c}\text { PKB PER CAPITA } \\
\text { SR UE }=100\end{array}$ & 48 & 61 & 65 & 80 \\
$\begin{array}{c}\text { BEZROBOCIE } \\
\text { WEDEUG DEFINICJI } \\
\text { EUROSTATU }\end{array}$ & 7,4 & 13,5 & 9,7 & 17,7 \\
\end{tabular}

* członek UE od I VII 2013 roku.

Źródło: na podstawie danych Eurostatu i Komisji Europejskiej 2013.

12 Department for Environment, Food \& Rural Affairs: Food and Forming, Making the food and farming industry more competitive, UK 2011. 
Analizując sytuację społeczną i ekonomiczną tych państw, można zauważyć, że rolnictwo, zatrudnienie w nim stanowi swojego rodzaju zabezpieczenie pozwalające zarówno na złagodzenie konsekwencji wysokiego bezrobocia, jak i niższego niż średnia UE poziomu gospodarczego - od 48 proc. w Rumunii do 80 proc. w Grecji. Rolnictwo i wieś redukują bowiem problem biedy. Co prawda na wsi jest jej na ogół więcej niż w miastach, ale bieda na wsi jest mniej dotkliwa na wsi nie ma ludzi szukających żywności w koszach na śmieci i nie ma tak bolesnego problemu bezdomności. W Polsce zagrożenie ubóstwem na wsi jest w większości województw dwu-trzykrotnie wyższe niż w miastach ${ }^{13}$. Podobny jego poziom w miastach i wsiach jest tylko na Śląsku, ale tam możliwości zatrudnienia poza rolnictwem i dwuzawodowości są znacznie większe niż w innych regionach.

Mieszkańcy wsi stanowią 38 proc. mieszkańców Polski, natomiast w populacji osób żyjących poniżej poziomu skrajnego ubóstwa (czyli poniżej poziomu określającego minimum egzystencji) stanowią oni 60 proc. ${ }^{14}$.

\section{Pozaprodukcyjne funkcje rolnictwa}

Funkcja produkcyjna jest wciąż wiodącym celem pracy w rolnictwie. Jednak dochód z pracy w rolnictwie nie jest już głównym źródłem dochodów rolniczych gospodarstw domowych UE. Wraz z rozwojem ekonomicznym coraz większa część gospodarstw osiąga

13 Główny Urząd Statystyczny, Ubóstwo w Polsce w świetle badań GUS, Warszawa 2013 (Studia i Analizy Statystyczne).

14 Główny Urząd Statystyczny, Ubóstwo w Polsce w świetle badań GUS, Warszawa 2013 (Studia i Analizy Statystyczne). 
pozarolnicze dochody, których źródłem jest albo dywersyfikacja działalności rolniczej (agroturystyka, alternatywna produkcja roślinna lub zwierzęca itp.), a przede wszystkim praca poza rolnictwem. Dobrym przykładem tego procesu jest m.in. Irlandia: do roku 2006 następował wzrost zatrudnienia poza rolnictwem, osiągając szczyt wynoszący 58 proc. rolniczych gospodarstw domowych, w których rolnik (mąż lub żona) mieli pracę poza rolnictwem. Tamten trend uległ jednak powolnemu odwróceniu i w roku 2012 było to 48,5 proc. gospodarstw ${ }^{15}$. Takie zmiany są możliwe wówczas, gdy w danym państwie lub regionie jest relatywnie dobra sytuacja na rynku pracy oraz gdy równolegle towarzyszą jej programy edukacyjne kształcenia ustawicznego, ułatwiające reorientację zawodową dla osób zatrudnionych $\mathrm{w}$ rolnictwie lub odchodzących od pracy $\mathrm{w}$ tym zawodzie. Działaniami w tym kierunku w Irlandii zajmuje się głównie doradztwo rolnicze ${ }^{16}$.

Oprócz produkcji żywności lub surowców do produkcji włókien lub biopaliw do funkcji obszarów wiejskich zalicza się także takie funkcje, jak:

- mieszkalna: z potrzebą rozbudowy odpowiedniej infrastruktury technicznej i społecznej;

- turystyczna i rekreacyjna: w tym turystyka wiejska i jej różne formy;

- środowiskowa: ochrona środowiska i zachowanie bioróżnorodności, dobrostan zwierząt.

15 The Irish Farmers' Association, „Farm Income Review” 2013; National Farm Survey, Ireland 2007.

16 Teagasc, Adult Training And Life Long Learning Programme. Knowledge Transfer, Education and Training, Ireland 2014. 
Polityka środowiskowa, ochrony zasobów naturalnych, jest przynajmniej w UE zrozumiała i ma odzwierciedlenie także w warunkach koniecznych do otrzymywania dopłat bezpośrednich i innych z funduszy UE. Duże znaczenie mają programy rolno-środowiskowe, będące instrumentem finansowym wspierającym ekologiczne aspekty produkcji rolniczej. Są one obowiązkowe we wszystkich krajach UE-28.

W Unii Europejskiej rolnictwo i ochrona środowiska muszą iść w parze. Nie jest to jednak ani oczywiste, ani stosowane na całym świecie. Rodzi się więc pytanie, czy bez dodatkowego wsparcia rolnictwo UE na pewno mogłoby wytrzymać konkurencję ze strony państw nieprzestrzegających takich wymagań. Obowiązkowe w UE dobrostan zwierząt i ochrona środowiska wiążą się z kosztami, często wysokimi, a więc powoduje to obniżenie konkurencyjności na rynkach międzynarodowych, jeśli jedynym kryterium byłyby czynniki ekonomiczne. Fair trade? Tak, ale przy respektowaniu takich samych zasad dotyczących produkcji, w tym ochrony środowiska i dobrostanu zwierząt hodowlanych.

Polityka społeczna związana w rolnictwem, a szerzej dotycząca mieszkańców obszarów wiejskich UE, ma szczególnie duże znaczenie. Przede wszystkim należy zaznaczyć, że na tych obszarach mieszka 60 proc. obywateli Unii. Pamiętając, że zatrudnienie w rolnictwie UE oceniane jest według różnych źródeł na około 5 proc., należy społeczny wymiar rolnictwa postrzegać nie tylko przez pracę bezpośrednio $\mathrm{w}$ rolnictwie. Wieś jest środowiskiem i warunkiem koniecznym istnienia takich elementów dziedzictwa kulturowego jak literatura, muzyka, architektura, kuchnia itd. Szczególnie ta ostatnia przeżywa w naszych czasach prawdziwy renesans. Żywność tradycyjna i lokalna jest szansą ograniczenia nega- 
tywnych konsekwencji produkcji o skali przemysłowej, wyłącznie komercyjnej.

W bazie Komisji Europejskiej zawierającej zarejestrowane produkty rolno-spożywcze, którym została przyznane prawo do nazwy Chroniona Nazwa Pochodzenia, Chronione Oznaczenie Geograficzne lub Gwarantowana Tradycyjna Specjalność, dominują produkty kultury wiejskich regionów. Obecnie (25 kwietnia 2014 roku) zarejestrowane są łącznie 1224 produkty. Liderami są od lat Włochy (264), Francja (211) i Hiszpania (178). Polska zarejestrowała 35 produktów, co jest dobrym wynikiem, szczególnie w grupie państw, które przystąpiły do Unii w 2004 lub w 2007 roku. Najwyżej cenione są produkty oznaczone ChNP (Chroniona Nazwa Pochodzenia), a więc te, które produkowane są w konkretnym, ściśle określonym regionie, z lokalnych surowców.

Ten rozwijający się segment rynku żywności jest więc w dobie wszechobecnej globalizacji ważny zarówno ze względów ekonomicznych, jak i społecznych i kulturowych, zwłaszcza ze względu na kulturę kulinarną. Rolnictwo, szczególnie rodzinne, jest naturalnym środowiskiem tego pozytywnego trendu umożliwiającego jeśli nie uniknięcie, to chociaż spowolnienie ciągłego procesu jej unifikacji.

Czesław Nowak, Ekonomiczne i społeczne znaczenie zatrudnienia w rolnictwie na przykładzie wybranych państw UE, [w:] Rodzina między praca a płaca. Refleksja nad spoteczna myśla encykliki Laborem exercens Jana Pawła II, red. Robert Kantor, Marek Kluz, Józef Młyński, Kraków 2016, s. 145-157. 